\title{
Core Talent Identification and Management Problems of the Enterprise
}

\author{
Xiaoqing Wang \\ Xi'an Jiaotong University City College, No. 8715, Shang Ji Road, Xi'an city, Shaanxi Prov. P.R. \\ China wang.xq@163.com
}

Keywords: Core talents; Talent management; Competency; HRM

\begin{abstract}
Talent management has become a focus problem in human resource management theory and practice. Firstly, the article reviews the related studies of the talent management theory and practice, and puts forward the meaning of the core talents, which can be divided into four types: management core talents, technical core talents, skills core talents and market core talents. In addition, this article builds up a three-dimensional structure model of core talents ability, and a talent management system based on competence quality model, especially some suggestions to corporate decision makers.
\end{abstract}

\section{Introduction}

In the era of knowledge and economy, talent is the most important resource of enterprises, it is the basic power for enterprise in market competition and development [1]. The quantity and quality of personnel and innovation ability is the key factor to economic growth and social progress [2]. With the enterprise competition, modern enterprise pays more attention on their own "talent strategy", and they tend to improve their talent management practices. In recent years, the talent management theory and practice in developed countries is constantly enriching, and gradually formed some new thinking of strategic talent management [3]. "Talent management" has become a hot topic in the study of human resource management. In China, although the amount of talent over 60,000,000, there is a shortage of high-level personnel still, and the aging phenomenon is serious, which means the enterprise will lack of talents in a long term[4]. Under the pressure of international competition, some outstanding enterprises such as Vanke, Lenovo have begun to take talent management practice and exploration, but the majority of enterprises and HR professionals don't have a clear concept on "talent management" [5]. According to a current survey which base on more than 300 enterprises in Shaanxi province, we found that Shaanxi enterprises have realized that enterprises should give them different attentions and development opportunities base on different categories of employees, especially for enterprises which have a long-term development. Although respondents have a certain degree for talent gives, but for what is a "talent", there is still a cognitive bias, 33\% of respondents didn't regard the core staffs as the talent employee; even though $62 \%$ of respondents believe that talent management strategy is important, but in management practice, they still complete some general personnel affairs. A number of enterprises never set up scientific performance management system, they think that the main purpose of performance management is just an element of bonus and position (72\%), which makes performance management like a performance appraisal. According to the survey, 69\% don't put the succession planning, leadership development plan, and performance evaluation and feedback as an important position. Also did not establish a scientific and effective talent strategy. Base on this background, this article will define enterprise's core talented employee, and try to build a system of enterprise core talent management framework.

\section{Research Status}

The Definition of Core Talent. Human resources management field current define that core talents have not form a unified concept, some scholars named it as "talent", some scholars use "core staff" to explain it, in this paper, we name it "Core Talent".

Based on the element quality and ability structure of high-level personnel Xuezhong Chen [6] think the high-level personnel refers to the people who have higher quality, advanced mental models, better 
communication level, strong ability of structure (including learning ability, innovation ability, strain ability, organizational ability, etc.), which means the people who make great contributions to the society. Shu-en wang think high-tech enterprise talent means one who have modern scientific theory knowledge and the specialized technical level, and have rich practical experience of high-quality scientific research[1]. Xin Liu [3] think that the talent management should be the employees who have high value or potential value, especially have an important impact on the replacing the organization's key positions. Li Changcang [7] believes that the core staff is the owner of key knowledge and skills also can be the vital people to whole enterprise's value. Lanham Lee [8] says that the core staff is the most difficult to find, the most hard to be replaced, they can ensure company's business strategies. Jian-ping shao [9] think core talents can be divided into two kinds: core ability talents and core applied talents. The core ability talents means people who work in various universities, and research institutes, below 45 years old, they have a doctorate or senior title of professional; Core applied talents refers to people who work in organizations, under 45 years old, have senior technical titles. Jue Nie[10] think that enterprise's core talent is the people who can in charge of the key positions in enterprises, companies need to judge talents by employees' ability and their value for companies. Xianqi Zhu[11] consider that core talents in the industry, specific enterprises or scientific research units of the important research and development department, at a particular stage of development, through personal or team the ability of the general and special factors of combination and its own unique characteristics, professional to create the core competence of the industry or enterprise value promotion key activities, its performance can be significantly for the sustainable development of the industry, or enterprise collection have a significant impact on employees. Zhong Lin[12] define "Core talents" from a strategic matching, performance, and 3D dynamic point of views. He think that only those people who have a difficult strategic matching degree, who have an outstanding performance, and can hardly replace by others, can be the core talents.

Through analysis shows, scholars define the core talented person from different angles, some scholars define it from the perspective of behavioral characteristics, some scholars judge it from the perspective of the ability and the value, some scholars define it from the position and function, while some scholars define it from the employee in the enterprise core technology, key resources, business management, and the role of strategic competitive advantage, etc. To sum up, the core talent has the highest value compare with other human capital, and it can be more independence and particularity. Core talents 'contribution to one company is much greater than the enterprise as the employer's investment.

The Kinds of Core Talent. Since the different definitions on core talent, scholars have the diversity perspectives on this. Generally speaking, people think the key position employees, researchers and main departments' employees belong to core talents. The author think that these employees are quite important, but enterprise likes a system, different employees have different positions, if they can create valued value to one company, they can be regarded as core talents. Jun Nie[10] divided core talents into two parts, they are technical talents, and management core talents. Yi ridge Zhao [13] divided core talents into four parts, they are management core staffs, marketing core staffs, technical core staffs and process core staffs. Peitong Jia [14] thinks that core talents should be professional staffs, public relationship staffs, management staffs. Xiao-hai Zhang [15] consider technical skill staffs, management staffs and hi-tech skill staffs combine the core talents.

Core Talents Competence. Core talent management system must be based on the core talents competence quality model, a clear core talents should have the ability structure and their combination relations. Domestic scholars have finished some analysis on ability structure of core talents, but not enough. Jun Nie [10] think enterprise's core talents ability is the main factors on finishing the enterprise's tasks.

Core talent management system must be based on the core talents competence quality model, to ensure core talents should have the ability structure and combination relations. Domestic scholars have finished some analysis on ability structure of core talents, but not enough. Jun Nie [10] think enterprise's core talents ability is the main factor on finishing the enterprise's tasks. It is high combination of physical fitness, skills, and intelligence. Feng-li Wang [16] think that core talented person's ability can be divided into basic ability and special ability, the basic ability refers to the ability of ordinary positions' 
requirements; Special ability is the different ability compare with others. Xianqi Zhu [11] thinks technology-based core talented person's ability structure including basic ability, special ability and professional quality. Basic ability means observation, attention, memory, imagination, etc.

Special ability can be divided into: (1) professional ability, it is mainly refers to science and technology talents of professional skills and professional skills;(2) potential ability, it includes the ability of re-learning, that is on the basis of the existing ability to get updated information and knowledge, and scientific research ability, and the re-learning ability can decide talent ability structure of an enterprise and the one nation. (3) Innovate ability, it mainly refers to relying on knowledge, building new ideas, new methods, and new scientific research ability. Professional quality includes strong professional sense of belonging (loyalty to professional), strong autonomy, unique values, high sense of mission, and strong achievement motivation, etc. During management practice, TCL corporation think that core competence can be divided into the talent innovation development, learning, coordination, analysis, judgment and implementation ability, and the essential quality includes learning, good faith, the mind, communication, and the passion of the five basic quality. As a result, there is no unified for core talented person ability structure currently, some people even think that the core talented person ability is based on the ordinary staff ability, and it just have a little increase.

\section{The Definition and Classification of Core Talents}

The author believes that the core talent is to point to the employees who in the enterprise business value, to complete the company's strategic goals, to maintain and improve competitive advantage. The author thinks that the enterprise's core talents should possess the following characteristics: Firstly, one is the key in business enterprise value chain, one can achieve enterprise's strategic target; Secondly, one have the corresponding professional expertise, personal qualities and autonomy; Thirdly, one have a high self-value pursuit and achievement motivation, Fourth, one has good individual performance and development potential; Finally, it is one highly agree the company's value, behaviors and perspectives.

Based on the definition of core talents, this paper divides into the core talent into management talents, research talents, skills talents, and marketing talents. For enterprises, four types of core talents play an important role, they have different expertise and skills respectively, and undertake different responsibility. Because these kinds of talents have a sense of responsibility, dedication and teamwork spirit, they can achieve good results. At the same time, these employees has a high agree to the enterprise idea, rules and regulations, they can provide support to companies.

Management Talents. Management talents are the knowledge workers engaged in creative activities, the nature of work is more complexity, risk, special, creative, and artistic. The content of the management activities involving people, goods, content and other aspects, knowledge management activities involving economic, political, legal, technical, personnel, and other disciplines. Managers to engage in creative work, to experience are dependence and helps in the past, to explore new things. Managers often deal with the complex relationship, there is no stable pattern can be applied, it is a combination of experience and knowledge. Manager's work often means indirect, their main task is decision-making, tracking, and results.

Research Talents. Research talents' work has the strong exploratory, creative, high risk demands, it is a special kind of productive labor, need massive investment support, and working time can be long, the relevant technical knowledge has high inheritance, and companies need retain them. Research staffs transfer the knowledge to reliable and creative products, researchers as the main knowledge employees, have some characteristics, like the high independent, the replacement costs is high, the liquid, the evaluation is difficult, the loose work environment and so on.

High-skilled Talents. Superb ability is the main characteristic of the skill talents, this ability is not only the traditional "craft" and some "skills", but in the modern engineering technology, on the basis of theoretical knowledge, through the enterprise skills training and practice accumulated for a long time, and get some production operation skills, it is a combination of both hands and brain. High-skilled talents generally hold the enterprise technology and precision manufacturing technology, they engaged 
in complex works, and show some creative works, such as technology innovation, technology improvement, and process reform, etc.

Marketing Talents. Marketing talents engaged in collecting market intelligence, testing market potential, analyzing sales data, and making marketing plan and strategy, this kind of work is more initiative, flexibility, service, contact resistance, additional and timeliness. Marketing employees need to develop customer resources, to look for potential customers, and to contact the customers. It is a kind of service, including before sales, during sales and after sales service; at the same time, the marketing is a kind of art, it try to use different methods to introduce products in the shortest possible time, let the customers understand products and purchase them.

\section{Core Talents Competence and Quality Model}

The Ability Structure of Core Talents. The author thinks that, based on the core value of talents in the enterprise, the core talents can be divided into basic quality, business ability and strategic cooperation, which can build up the core talent ability structure system (Table 1).

A Competent Quality Model of the Core Talented Person. In the three-dimensional structure of core talent, basic quality is a definition of social role and self-characteristic, it decide employees' cognitive and positioning of work motivation, provide the main influence to performance and development staffs; Business ability is the basis of the employee completes the tasks, but the knowledge structure can through further study and be able to change, and professional skills are shown by employees work ability and performance, is the employee's basic literacy for the knowledge structure of the utilization degree of performance; Strategic cooperation pay attention to the development of employees, including employees' active learning and change their own knowledge structure to meet business development needs, change the ways of working to achieve the enterprise strategic target, reflect the employees cooperation with corporate strategy, shows long-term contribution and the sustainable development potential. (Figure 1)

In the process of constructing the model of core talent competency, enterprises first should make enterprise's strategic goal and human power resource plan clear; find the key factors that influence the realization for the goal of enterprise's strategic goal; study enterprise's challenges; define the concrete content of second-class capacity dimensions in the six first-class capacity indexes---the occupational attitude, sense of belonging, knowledge structure, professional skill, learning innovation, and overall viewpoint for the talents in different classes and levels; initially shape the framework of core talent competency model in different jobs and classes by combining with the company culture and internal and external environment based on the structure of 3D capacity of core talent. Then, enterprises should acquire the data of core talent competency ability with the methods of behavior event interview and questionnaire; refine to the competency indexes that the core talent should have after classifying and analyzing. Finally, enterprises should define the levels and classes of the second-class capacity dimension; make concrete definition and description to each class in each dimension; shape the model of core talent competency with classes and levels by making deeper analysis on the competency of the core talent who works in the key post with excellent performance.

\section{Core Talent Management Based On The Model Of Competency}

On the basis of model of competency quality, modern enterprises should establish the core talent management system including core talent employment, core talent store, core talent motivation, core talent performance management, core talent training development, core talent career management which should embrace the competency (Figure 2) to strengthen the support to the emotion, material, and career of core talent; to play the leading role of core talent in enterprise culture and enterprise value; to accept the value and performance of core talent; to provide the platform and opportunity for the core talent to bring their capacities into play to make the core talent become the core force in the different businesses in the enterprise and to make the core talent play the irreplaceable role in the improvement of 
operation performance, the stable development of enterprise, management reform and technology reform of enterprise, and the realization for the long-term strategic goal of enterprise.

Table 1 Core talents 3D ability structure

\begin{tabular}{|c|c|c|c|c|c|}
\hline \multirow[b]{2}{*}{$\begin{array}{l}\text { Types of } \\
\text { ability }\end{array}$} & \multirow{2}{*}{$\begin{array}{l}1^{\text {st }} \text { level } \\
\text { ability }\end{array}$} & \multicolumn{4}{|c|}{$2^{\text {nd }}$ level ability } \\
\hline & & $\begin{array}{l}\text { Management } \\
\text { talents }\end{array}$ & $\begin{array}{l}\text { Research } \\
\text { talents }\end{array}$ & High-skilled talents & Marketing talents \\
\hline \multirow{3}{*}{$\begin{array}{l}\text { Element } \\
\text { quality }\end{array}$} & \multirow{2}{*}{$\begin{array}{l}\text { Professional } \\
\text { attitude }\end{array}$} & \multicolumn{4}{|c|}{ Responsibility; initialization; Loyalty; Confidence } \\
\hline & & $\begin{array}{l}\text { Affinity } \\
\text { influence }\end{array}$ & Tough & Discipline & Persistent \\
\hline & Attribution & $\begin{array}{l}\text { Dedicated \& } \\
\text { Competitive }\end{array}$ & $\begin{array}{l}\text { Dedicated \& } \\
\text { Competitive }\end{array}$ & Dedicated & Dedicated \& Faith \\
\hline \multirow{2}{*}{$\begin{array}{l}\text { Business } \\
\text { Ability }\end{array}$} & $\begin{array}{l}\text { Knowledge } \\
\text { Structure }\end{array}$ & $\begin{array}{l}\text { Management } \\
\text { Economics } \\
\text { Laws } \\
\text { Psychology } \\
\text { Sociology } \\
\text { Company } \\
\text { knowledge }\end{array}$ & $\begin{array}{l}\text { Engineering } \\
\text { Electrical } \\
\text { Mechanical } \\
\text { Computer } \\
\text { Information } \\
\text { technology } \\
\text { Company } \\
\text { Knowledge }\end{array}$ & $\begin{array}{l}\text { Professional skill } \\
\text { Productions } \\
\text { knowledge }\end{array}$ & $\begin{array}{l}\text { Marketing } \\
\text { Economics } \\
\text { Management } \\
\text { Economic Laws } \\
\text { Psychology } \\
\text { E-Business } \\
\text { Logistics } \\
\text { Company } \\
\text { Knowledge }\end{array}$ \\
\hline & $\begin{array}{l}\text { Academic } \\
\text { Skill }\end{array}$ & $\begin{array}{l}\text { Supervision } \\
\text { Decision } \\
\text { Communicate } \\
\text { Strategic Goal } \\
\text { of anagement } \\
\text { Teamwork } \\
\text { Control } \\
\text { Confidence }\end{array}$ & $\begin{array}{l}\text { Creation } \\
\text { Design } \\
\text { Time } \\
\text { Management } \\
\text { Project } \\
\text { Management }\end{array}$ & $\begin{array}{l}\text { Quality protection } \\
\text { Transfer } \\
\text { Process } \\
\text { Cooperation、 } \\
\text { Facility } \\
\text { Management Safe } \\
\text { Management }\end{array}$ & $\begin{array}{l}\text { Analysis } \\
\text { Planning } \\
\text { PR } \\
\text { Maintenance }\end{array}$ \\
\hline \multirow[b]{3}{*}{$\begin{array}{l}\text { Strategic } \\
\text { Cooperation }\end{array}$} & \multirow{2}{*}{$\begin{array}{l}\text { Learning } \\
\text { Creation }\end{array}$} & $\begin{array}{l}\text { Self-learning, } \\
\text { Innovation }\end{array}$ & $\begin{array}{l}\text { Creation } \\
\text { Sensitivity }\end{array}$ & $\begin{array}{l}\text { New skill } \\
\text { application }\end{array}$ & $\begin{array}{l}\text { Marketing } \\
\text { Sensitivity }\end{array}$ \\
\hline & & \multicolumn{4}{|c|}{ Active learning and apply new knowledge and technology } \\
\hline & $\begin{array}{l}\text { All-round } \\
\text { Concept }\end{array}$ & $\begin{array}{l}\text { Achievement } \\
\text { orientation } \\
\text { Strategic } \\
\text { concept } \\
\text { Customer } \\
\text { awareness }\end{array}$ & $\begin{array}{l}\text { Achievement } \\
\text { orientation } \\
\text { Strategic } \\
\text { concept } \\
\text { Customer } \\
\text { awareness }\end{array}$ & $\begin{array}{l}\text { Achievement } \\
\text { orientation } \\
\text { Cost awareness } \\
\text { Risk prevention } \\
\text { consciousness }\end{array}$ & $\begin{array}{l}\text { Cost awareness } \\
\text { Customer } \\
\text { awareness } \\
\text { Risk } \\
\text { management } \\
\text { consciousness }\end{array}$ \\
\hline
\end{tabular}




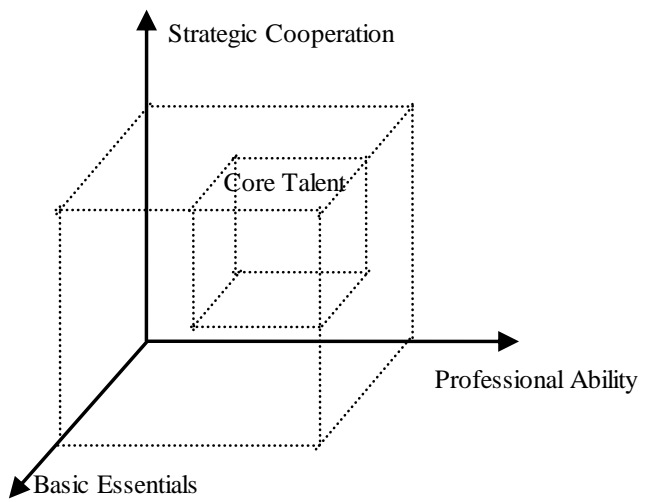

Figure 1. 3D ability

core talented person

structure defined by the

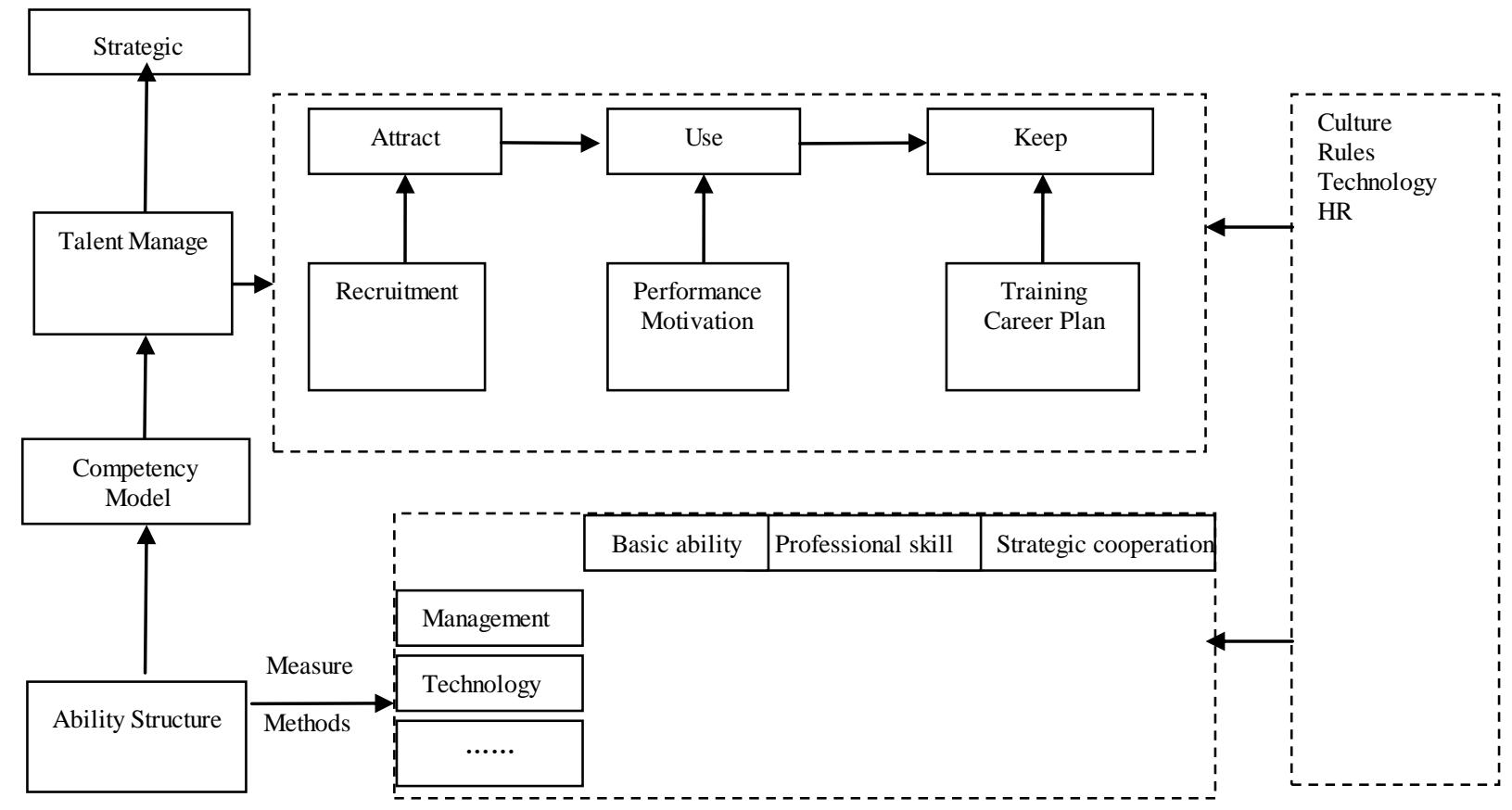

Figure 2 Core talent assessment and management model

Just as shown in the Figure 2, the core talent management includes three parts----attraction, use, and retain and development. The attraction to the core talent mainly refers to the recruitment to external talent and the identification and selection to internal core talent. The use to the core talent refers to the motivation, performance management, and skill training to core talent. The retain and development to core talent refers to the development of potential ability, the succession plan of management post, and the career management to the core talent. The elements of culture, system, technology, and human resource system for the internal conditions of enterprise management are the basic assurance conditions of enterprise's core talent management.

On the attraction to core talent, enterprises should work out the recruitment and introduction policy for the core talent to strengthen the working force of core talent store; deal with the selection and development of store talent based on the capacity model of core talent. Enterprises should solve the problems of severe shortage and bad quality of core talent team in different classes as soon as possible; strengthen the cohesion and development of core talents on management, technology, skill, and marketing to establish a core talent team with high level and reasonable structure. The special distribution methods should be taken to the special talents for the development of enterprise. Multiple 
forms such as annual salary system, agreement salary, and benefit bonus can be tried. According to their value contribution, the first-class salary should be provided to make the core talent's individual benefit goal and company's long-term development goal be consistent. On the selection and use of core talent, enterprises should work out the talent development and work out the post standards and management system for core talent in accordance with the competency model's definition and requirement to the core talent capacity. Enterprises should establish the scientific core talent career management plan and establish the career development passage which is suitable for the core talent in different orders. Enterprises should lead in the competition system; complete the use, assessment, and motivation system of core talent; complete the system for staying the talent to attract the core talent with the conditions of career, culture, management, environment, and treatment. Enterprises should optimize and complete the motivation salary management mode; establish the salary system which is favorable to the high-level professional talent and key post; break the traditions of absolute equalitarianism and putting over emphasis on performance and contribution; bring the direct motivation effect of salary to the maximum degree. Enterprises should create good atmosphere for growth, including policy condition, business condition, learning condition, living and cultural condition, and social security condition.

On the retain and development of core talent, by establishing and completing enterprise's core talent bank and core talent assessment mechanism based on the core talent assessment system in the competency model, create the jobs that can make core talents shoulder key project, research topic, operation management, new product development, and technological breakthrough to develop and improve their practical work ability; pay more attention to the education and training of political quality, ideological quality, and mental quality; adopt the special training and job rotation to cultivate and provide the chance of taking post and to build and develop the back-up core talent team. Optimize age, knowledge, and professional structure of the current core management talent team; strengthen the cultivation; complete the management post level system; shape the occupational development passage that can motivate the management level and ability to improve. Strengthen to cultivate and support the young technological talent; support their project; encourage and support the excellent young staff to open the innovative research work independently to assure the sustainable development of technological talent team. Actively promote the international communication of technological core talent; open the cooperative research; cultivate talents in the international competitive cooperation; make efforts to make the innovation ability of the technological talent team make rapid progress in the industry. Open the technological training, job rotation, and quality cultivation to the technological core talents; deal with the inheritance and help of post skills.

\section{Conclusion}

Talent management is the hot problem of the theory and practice of human resource management. The paper, with the analysis on the domestic management theory and current situation of practice for core talent, points out the problems that the definition of core talent is vague, and the management theory and method for core talent is short; argues that the core talent refers to the staff who plays the key role in the realization of company's strategic goal, the maintenance and improvement of competitive advantage, and the creation and realization of customer value in the links of enterprise's business value chain, or the staff with potential key effect; argues that core talent has the features of high value, high quality and ability, high sense of achievement, high performance and potential, and high cultural identification. The paper, with the further analysis, divides the core talent into management core talent, technology core talent, skill core talent, and market core talent; divides the ability of core talent into basic quality, business ability, and strategic coordination; establishes the 3D structure model of core talent; constructs the core talent management system based on the competency model.

The talent management system based on the competency is an attempt for solving enterprise's practice problem of talent management. For the concrete enterprise, due to the different enterprise types, businesses, development phases, scales, cultures, and conditions, their problems are different. They may have the unique best management practice. The paper only provides a thinking and framework for 
enterprise to manage talent. Enterprise should select and confirm the concrete management measures and methods about how to define, classify the core talent and how to select capacity dimension.

\section{References}

[1] Wang Shu'en,Li Xiaoxia. Talent Management Research In Hi-new Technique Enterprises, SCIENTIFIC MANAGEMENT RESEARCH,Vol.24, No.2, 2006, pp.108-110

[2] LIU Xiao-qin,Disadvantage and the countermeasure of Talent management mechanism in China, JOURNAL OF NANJING COLLEGE FOR POPULATION PROGRAMME MANAGEMENT, Vol.24, No.2, 2008,pp.68-72

[3] Liu Xin,New thinking and enlightenment of the international talent management strategy,Jianghai Academic Journal, No.3, 2010,pp.91-97

[4] Http://www.china.com.cn/zhuanti2005/txt/2004-12/28/content_5740794.htm

[5] Institute of labor and personnel,Talent management: a new era of human resources management, Renmin university of China:2010

[6] Chen Xue-zhong,High-level talents converging pattern and development strategy , SCIENCE AND MANAGEMENT,Vol.26, No.4, 2006, pp.14-16

[7] Li Chang-cang,How to manage the core staff,Peking University Press:2005.1

[8] Leigh Branham,Retain the core staff,China labor \& social security publishing house:2004

[9] Shao Jianping, An Empirical Study on the Relationship between the Brain Drain of Core Talents and Degree of Regional Identity in the Underdeveloped Areas,Science \& Technology Progress and Policy,Vol.29, No.13, 2012,pp.28-31

[10] NIE Jun,Identification and Matching Model for the Core Talents and KeyPositions of Enterprises ,JOURNAL OF ENGINEERING MANAGEMENT,Vol.25, No.1, 2011, pp.115-119

[11]Zhu Xianqi ,Analysis and Definiens of Convergent-Effective Function Model on Area-Technology Core Talents,SCIENCE \& TECHNOLOGY PROGRESS AND POLICY,Vol.27, No.9, 2010,pp.30-34

[12] LIN Zhong,A Dynamic Core-Employee Identification Model Based on the Perspective of Strategic Match,RESEARCH ON FINANCIAL AND ECONOMIC ISSUES,No.12, 2008, pp.94-100

[13]Zhao Yiling,Research to The core employees contributed to the intellectual capital elements ,COMMERCIAL TIMES,No.4, 2009,pp.38-39

[14] Jia Peitong, The present situation and countermeasures of the enterprise core staff management ,Chinese and Foreign Entrepreneurs,No.22, 2014,pp.166-167

[15] Zhang Xiaohai,Core talent management and team construction of state ownership enterprise ,China Business Monthly,No.10, 2012,pp.82-83

[16] Wang Feng-li ,Analysis and Utilization of Enterprise's Core Talents ,journal of china agricultural university (social sciences edition) ,No.1, 2005,pp.66-69 